\title{
TRACTION CONDITIONS OF AGRICULTURAL TRACTORS MANUFACTURED AND MARKETED
}

\author{
YUVRAJ G. KASAL* \& POONAM P. SHETE \\ School of Agriculture, Lovely Professional University, Phagwara, Punjab, India
}

\begin{abstract}
Currently in India there is an obligatory child care centre and a few studios that to determine the yield of agricultural tractors. The performance problems are hitting them manufacturers, and because the official disclosure of reports is not required, consumers only have the information of the manufacturer. Therefore, the objective of the present study was to evaluate the traction conditions of the agricultural tractors in relation to four power ranges and the type of traction. For this, it was analysed in a universe of 191 tractors, the following parameters: maximum estimated strength of the traction bar traction (BT) and strength / weight ratio. Some of these parameters were evaluated in different conditions of solo and ballast. The results show that the tractor models in the power range of $147 \mathrm{~kW}$ and $4 \times 2$ of TDA traction showing the highest values of maximum traction strength Preview. The maximum traction strength is superior for tractors in the $147 \mathrm{~kW}$ band and $4 \times 2$ TDA traction.
\end{abstract}

KEYWORDS: Traction, tractor and Power

Received: Nov 28, 2020; Accepted: Dec 18, 2020; Published: Dec 24, 2020; Paper Id.: IJMPERDDEC202059

\section{INTRODUCTION}

The tractor is the main mobile source of power used to perform the various tasks required in agricultural production processes. Knowing well about the tractor performance allows manufacturers to develop more efficient products in such a way that farmers get better benefit of the operational characteristics of this machine (GABRIEL FILHO et al., 2008). The industry makes available on the market various types and models of agricultural tractors, in power ranges from 15 to $320 \mathrm{~kW}$. Second ANFAVEA (2012), the manufacture of the main manufacturers in 2012 was distributed as follows; Massey Ferguson (17,085 units), Agrale (1,987 units), Case (1,529 units), New Holland (16,391 units), John Deere (10,933 units) and Valtra (14,784 units), totaling 62,709 units of agricultural tractors. The evaluation of performance parameters agricultural tractors is essential to generate information that allows the farmer to know the machine and make the appropriate sizing of the mechanized set for resource optimization. In addition to the correct sizing of the set tractor-implement, it is essential to choose the adequate time to intervene on the ground and ensure correct adjustments of engine speed, ratio gearbox transmission pressure, pressure of inflation of the tires and the ballast of the tractor (SERRANO, 2007). The use of Auxiliary Front Traction (ADT) in two-wheel drive tractors (2RM) with power above $75 \mathrm{~kW}$ spread in India from 1980s. This trend reached, more later, less powerful tractors. The effectiveness of TDA on these tractors has been proven by several researchers (MACHADO et al., 2010). In view of this, it was aimed with the present work to evaluate the traction conditions of tractors in relation to power ranges and type of traction. 


\section{MATERIAL AND METHODS}

The trial was conducted by the Mechanization Laboratory in the Department of Agricultural Engineering at the Federal University from Viçosa, Viçosa-MG. The data were collected 191 agricultural tire tractors manufactured or marketed in India under the Agrale, Case, Green Horse, John Deere, Landini, Massey Ferguson, New Holland, Tramontini, Valtra and Yanma. O data survey was carried out in the period from July 2010 to May 2013 consulting the technical specifications of manufacturers, tests and measurements "in loco" of specimens.

The tractors were separated into groups stratified four-band power (kW), according to ANFAVEA (2012), called, respectively, as light $(\leq 36 \mathrm{~kW})$, medium $(37 \leq \mathrm{P} \leq 73 \mathrm{~kW})$, heavy $(74 \leq \mathrm{P} \leq 146 \mathrm{~kW})$ and super heavy loads $(\geq 147$ $\mathrm{kW}$ ), described here as power I, II, III and IV, respectively. The maximum tensile force estimated at drawbar for tractor stability was determined by equation 1 , under conditions with and without ballast, established by ABNT NBR 10.400 (1997).

"FTM $\leq "$ "0.8 PDE DEE" / "HB" (1)

Where

FTM $=$ estimated maximum tractive force $(\mathrm{N})$;

$\mathrm{PDE}=$ static front weight $(\mathrm{N})$;

$\mathrm{DEE}=$ Wheelbase $(\mathrm{m})$;

$\mathrm{HB}=$ Drawbar height from plane support to the upper face of the drawbar (m).

Manufacturers do not provide Weight Static Front (PDE) of the tractors, and as not it was possible to weigh the front axle of the 191 models analyzed, test results were used and it was observed that on average the PDE was about 35 and $40 \%$ of the total weight for $4 \times 2$ and $4 \times 2$ TDA tractors, respectively; this percentage was used for tractors with and without ballast. The relationship between traction force and weight was determined, in percentage, with and without ballast and compared according to CENEA (1982), which considers a ratio below $65 \%$ unacceptable, between 65 to $75 \%$ low, between 75 to $85 \%$ reasonable and above $85 \%$ good. This relationship, also known as traction efficiency, is a function of weight distribution on axles, tire types and surface conditions and represents the tractor's ability to use its weight in favor of traction force (Equation 2).

"R"_("FTM" / "PT") "=" "FTM" / "PT" (2)

Where,

RFTM / PT = Traction force / weight ratio (\%);

FTM $=$ estimated maximum tractive force $(\mathrm{N})$;

PT $=$ Weight of the tractor with ballast and without ballast, $(\mathrm{N})$.

In India, many tractor manufacturers do not make essential information available in the catalogs that assist in the proper selection of the specimen.

Technicians and farmers not having access to these information, which is often difficult to be measures on the property, depending on the structure necessary, make a superficial assessment to deciding for this or that model, for 
example, is difficult to imagine in India that producers have a dynamometer in the workshop, for strength testing maximum power take-off (TDP). In this way, the number of tractors for each characteristic varied in depending on the availability of necessary information for your pet. The data were analyzed using descriptive statistics tools and was based on in the total of tractors that contained the information necessary and the results presented by the average, standard deviation and coefficient of variation.

\section{RESULT AND DISCUSSIONS}

The results indicated that the traction force maximum increase with tractor power. The deviation reduced in the smallest power ranges, since the coefficient of variation in all power ranges oscillated between 21.51 to $40,48 \%$, with the lowest $\mathrm{CV}$ with and without ballast was obtained in the range of tractors with greater power. The variability of the data, with relation to the power bands, was lower in the IV range, with and without ballast (Table 1). The maximum tractive force of tractors fall in the IV power range, for example, it was bigger with and without ballast. This was due to the the fact that tractors in that range present auxiliary front. Increasing the power range is directly related to the increase in power available for any condition of the ground. Therefore, it is justified to increase the maximum tractive force with elevation of the range of power. Assessing surface conditions of the soil, GABRIEL FILHO et al. (2010a) concluded that it interfered with the tractor's ability to develop traction, since most parameters performance related significant variations throughout the tests.

Table 1: Maximum traction force with ballast and without ballast, depending on the power range of the tractors

\begin{tabular}{|l|l|l|l|}
\hline \multirow{2}{*}{ Sr. No. } & \multirow{2}{*}{$\mathbf{N}$} & \multicolumn{1}{c|}{ FTM \pm sx (N) } & \multirow{2}{*}{ CV (\%) } \\
\cline { 3 - 4 } & & With Ballast & \\
\hline I & 20 & $23.868,81 \pm 7.818,74$ & 32,76 \\
\hline II & 70 & $49.483,74 \pm 16.316,85$ & 32,97 \\
\hline III & 30 & $104.238,02 \pm 39.558,62$ & 37,95 \\
\hline IV & 12 & $219.805,15 \pm 47.282,85$ & 21,51 \\
\hline & & Without Ballast & \\
\hline I & 20 & $20.086,24 \pm 8.131,05$ & 40,48 \\
\hline II & 74 & $39.366,67 \pm 11.679,29$ & 29,67 \\
\hline III & 33 & $83.288,80 \pm 32.620,63$ & 39,16 \\
\hline IV & 12 & $163.043,64 \pm 46.699,99$ & 28,64 \\
\hline
\end{tabular}

The results showed that one of the purpose of the ballast is to increase the tractive force maximum. Because it was found that with the addition of ballast, the FTM values were higher for all the power ranges compared to tractors without ballast. These results corroborate MONTEIRO et al. (2009 and 2011), who studied the influence of variation of the liquid ballast in the tire for the track with mobilized surface, in the traction force, having obtained lower values of force in the drawbar in the condition without ballast, and the other conditions (40 and $75 \%$ water) did not differ; results Similar results were also obtained by BARBOSA et al. (2005).

The type of traction present in the specimen interferes with the maximum available tractive force. The results showed that $79 \%$ of the tractors analyzed had auxiliary front traction; corroborating the statement that there was in the last years a significant increase in the number of tractors produced and / or marketed in India that presents this transmission. The maximum pulling force was higher in tractors equipped with TDA and the deviation standard and coefficient of 
variation in relation to the variable were lower than in specimens with $4 \times 2$ traction. Maximum traction force on tractors with $4 \times 2$ traction showed less variability in compared to the 4x2 TDA traction, perhaps due to the smaller number of specimens present in sample A maximum tractive force for tractors with the option of auxiliary front-wheel drive is higher when compared those without traction on the front axle and can reach even higher values with the addition of ballasts. These results interfered with the transfer weight from the front axle to the rear axle was greater in the 4x2 TDA tractors, obviously, Therefore, the maximum force available to this group was considerably higher.

Table 2: Maximum traction force with and without ballast, depending on the type of traction of the tractors

\begin{tabular}{|l|l|l|l|}
\hline \multirow{2}{*}{ Traction } & \multirow{2}{*}{$\mathbf{n}$} & \multicolumn{1}{c|}{ FTM \pm sx (N) } & \multirow{2}{*}{ CV (\%) } \\
\cline { 3 - 4 } & & \multicolumn{1}{|c|}{ With Ballast } & \\
\hline 4 X 2 & 33 & 46.16 & 37.42 \\
\hline 4 X 2 TDA & 101 & 81.48 & 80.34 \\
\hline & & Without Ballast & \\
\hline 4 X 2 & 33 & 35.34 & 36.28 \\
\hline 4 X 2 TDA & 106 & 64.65 & 75.52 \\
\hline
\end{tabular}

The transformation that occurred in tractors in relation to traction, going from $4 \times 2$ to $4 \times 2$ TDA, resulted in an increase of $56.6 \%$ and $54.7 \%$ for the traction force with and without ballast, respectively. The values found were higher than those obtained by SPAGNOLO et al. (2010 and 2013). However, tractors analyzed in this work were equipped with wider tires, which may explain such results. Tyre dimensions your contact area along with the load on wheelsets and the type of influence the maximum potential force on the bar traction. The relationship between traction force and weight of the tractor was higher for specimens with higher; this has occurred, as the power was higher for all studied tractors. $\mathrm{O}$ standard deviation followed this behavior and increased with the power range, whereas the coefficient of variation of the tractor pull-to-weight ratio was greater in the power range of 37 to $73 \mathrm{~kW}$ with and without ballast. The evaluation of the traction force ratio by weight, with and without ballast, is considered good, since all the values are above the reference, which is $85 \%$, of according to CENEA (1982). It can be seen that all values were above $100 \%$. This means that tractors in the four power ranges, with and without ballast, they can pull a value higher than own weight. A justification for this increase may be due to the greater tractive force with the increased power range. The variability of the data, with respect to specimens of power less than $36 \mathrm{~kW}$, of the traction force tractor weight was lower, with and without ballast. Agricultural tractors are exposed to efforts extreme conditions under working conditions, soil preparation and sowing, maybe they are the ones that most require a good relationship between the pulling force and the weight of the tractor. Seeders can demand approximately $10 \mathrm{hp}$ per line, and currently, machines are available on the market up to 42 planting lines, results similar to those obtained by ŠMERDA and UPERA (2010); PALM et al. (2010). One of the factors that most contributed with the greatest weight of the seeders was the advent of direct sowing in the straw, requiring more machines heavy to cut straw, The relationship between the pulling force and the weight of the tractor was higher in specimens with front-wheel drive help. Standard deviation and coefficient of variation observed data were also lower when the tractor presented auxiliary traction with and without ballast (Table 3). The traction-to-weight ratio is greater on tractors with the option of auxiliary front-wheel drive. This is probably due to the fact that they are tractors with greater power availability and greater strength maximum traction. Wheelsets are components important in this relation, in specimens with traction 4x2 TDA, the absolute increase in traction force and weight, is one of those responsible for the greatest relationship, corroborating results obtained 
by GABRIEL FILHO et al. (2010).

Table 3: Ratio of traction force to the weight of the tractor, with and without ballast, depending on the type of traction of the tractors

\begin{tabular}{|c|c|c|c|}
\hline \multirow{2}{*}{ Traction } & \multirow{2}{*}{ n } & FT/PT $\pm \mathbf{s x}(\%)$ & \multirow{2}{*}{ CV (\%) } \\
\hline & & With Ballast & \\
\hline $4 \times 2$ & 33 & 140.41 & 24.30 \\
\hline \multirow[t]{2}{*}{4 X 2 TDA } & 101 & 151.57 & 19.45 \\
\hline & & Without Ballast & \\
\hline $4 \times 2$ & 33 & 137.91 & 24.23 \\
\hline 4 X 2 TDA & 106 & 149.02 & 18.78 \\
\hline
\end{tabular}

The greater adherence obtained in front-wheel drive tractors is also one of the parameters that affect this relationship, inducing the relationship in favor of the traction force. The addition of ballast under certain working conditions, allows greater adherence and operational performance of tractor, MONTEIRO et al. (2013), also obtained similar conclusions.

\section{CONCLUSIONS}

The maximum tractive force is greater for tractors with power above $147 \mathrm{~kW}$ and $4 \times 2$ traction Ballast TDA. The addition of ballast can improve performance of agricultural tire tractors manufactured and / or marketed in India. The methodology used was efficient for the determining the performance parameters of tractors.

\section{REFERENCES}

1. ABNT - Brazilian Association of Technical Standards, NBR 10.400., 1997, Agricultural tractor. Performance determination on the drawbar. Test Method. São Paulo: ABNT. $4 p$.

2. ANFAVEA, 2014, National Association of Motor Vehicle Manufacturers. Statistical yearbook. Available at: http://www.anfavea.com.

3. BARBOSA, J. A .; VIEIRA, L. B .; DIAS, G. P .; DIAS JUNIOR, M. S., 2005, Operational performance of a tractor farm equipped alternately with radial and diagonal tires. Agricultural Engineering, Jaboticabal, v. 25, n.2, p. 474-480.

4. CENEA, 1982 - National Center for Agricultural Engineering. Parameters for proper selection of agricultural tractors of wheels.. 23p. (Technical Bulletin, 1).

5. Gabriel Filho, Soranso, A. M, A., Lopes, A., de Souza, E. G., Dabdoub, M. J., Furlani, C. E. A., \& da Camara, F. T. (2008). Dynamic performance of an agricultural tractor utilizing distilled biodiesel from spent oil. Revista Brasileira de Engenharia Agrícola e Ambiental, 12(5), 553-559.

6. GIMENEZ, L. M .; MILAN, M. , 2007, Diagnosis of mechanization in a grain producing region.Engineering Agrícola, Jaboticabal, vol. 27, n. 1, p. 210-219.

7. Machado, G., Chagnon, G., \& Favier, D. (2010). Analysis of the isotropic models of the Mullins effect based on filled silicone rubber experimental results. Mechanics of Materials, 42(9), 841-851.

8. MONTEIRO, L. A .; LANÇAS, K. P.; GUERRA, S. P. S. , 2013, Performance of an agricultural tractor equipped with radial and diagonal tires with three levels of liquid ballast. Agricultural Engineering, Jaboticabal, v. 31, n. 3, p. 551-560. 
9. SERRANO, J. M. P. R. , 2007 Performance of agricultural tractors in traction. Brazilian Agricultural Research, Brasilia, v. 42, n. 7, p. 1021-1027. 